\title{
Determination of Fatty Acid Composition of Food Containing Short Chain Fatty Acids
}

\author{
Nobuko KAWAI, Yukuho NAKAYAMA, and Kiyoshi SASAKI \\ Osaka City Institute of Public Health and Environmental Sciences \\ (8-34, Tojo-cho, Tennoji-ku, Osaka)
}

\begin{abstract}
Because of the high volatility and water solubility of short chain fatty acids and their methyl esters, analysis of the fatty acid composition of food lipids in which they are present is more difficult than that of lipids containing only long chain fatty acids. The GLC analysis of such lipids of small amount (about $100 \mathrm{mg}$ ) was established in the present study as follows : a lipid was methylated with diazomethane and $\mathrm{Na}$-methylate, and the produced fatty acid methyl esters were extracted in $n$ hexane. The short chain $(4 \sim 13$ and $16: 0)$ fatty acid methyl esters were measured by temperature programmed (GLC on 15\% OV-275 column, and long chain (14 24) fatty acid methyl esters by iso= thermal GLC on a suitable column for the analysis of fatty acid methyl ester such as DEGS. To determine the complete fatty acid (4 24) composition, these data of fatty acid methyl esters contents were combined by mediation of methyl palmitate amount, since palmitic acid is the major fatty acids in many food lipids. The fatty acid composition of butter fat, margarine (containing milk fat) fat and coconut oil was determined, and the recovery of lipid as total fatty acid methyl esters was $97.6 \%$ butter fat, $98.5 \%$ margarine fat and $97.9 \%$ coconut oil, respectively.
\end{abstract}

\section{Introduction}

The importance of the fatty acid composition of the food lipid in the determination of its nutritive value is proved by many biochemical studies on lipids. In recent years, many pro $=$ cessed foods containing butter or coconut oil have appeared on the market, and their lipids contain considerable amount of short chain fatty acids. However, there are comparatively few data available on the fatty acid composition of foods containing short chain fatty acids. Many years ago, the volatile and water soluble short chain fatty acids were analysed by alka= line titration after steam distilation to assess the milk fat quality, using the Reichert-Meiss1 ${ }^{1)}$ or butyric acid values ${ }^{2)}$, for example. However, these methods cannot measure the content of each fatty acid, and these values vary according to the lipid amount analyzed.

In recent years, gas liquid chromatography (GLC) has been applied to the determination of short chain fatty acid methyl esters. How = ever, there are some difficulties in GLC analysis of short chain fatty acid methyl ester compared with that of long chain fatty acid methyl ester. Because of the high volatility of the short chain fatty acids and their methyl esters, the conden= sation of their solution by heating or evapora $=$ tion must be avoided, and due to their water solubility, the recovery of short chain fatty acid methyl esters by extraction in organic solvent is considered to be somewhat low. As different from long chain fatty acid methyl esters, the sensitivity of the GLC peak area of short chain fatty acid methyl esters decreases with shortness of their carbon chain, so correce tion of the sensitivity of their peak area is necessary for GLC analysis. Furthermore, some organic solvents such as methanol, benzene or chloroform, interfere with GLC peak of methyl butyrate.

Christopherson et al. ${ }^{3)}$ established the analy= tical method of fatty acid composition of milk fat by GLC as follows: a stoichiometric amount of $2 \mathrm{~N}$ methanolic alkali (Na-methylate or $\mathrm{KOH}$-methanol) was added to the petroleum ether solution of lipid, and the obtained petros leum ether solution of fatty acid methyl esters was analysed by the temperature programmed 
GLC on 15\% DEGS column. Their method prevented the interference of methanol with methyl butyrate analysis and the loss of short chain fatty acids or their methyl esters. At the joint meeting of IDF, ISO and AOAC in 1975, the analytical method ${ }^{4}$ of short chain fatty acid methyl esters with GLC was discuss= ed for the purpose of detecting foreign fat in milk fat: a lipid was methylated with metha= nolic-KOH as with Cristopherson's method ${ }^{3)}$ and analysed by temperature programmed GLC on 5\% PEGA column. But even now, this method is not adopted as the standard method of IDF, ISO or AOAC. Iwaida et al. ${ }^{5)}$ reported an improvement of this method by way of isothermal GLC analysis of short chain fatty acid methyl esters, so as to analyse many samples in a short time. Their method was adopted under the Standard Methods of Analy= sis for Hygienic Chemists (Pharm. Soc. Jap.) under the item of the GLC analysis of short chain fatty acid ${ }^{5}$.

These methods present some problems, for quick operations are required for analysis, be $=$ cause the fatty acid methyl ester is treated as an intermediate material of lipid hydrolysis reaction. Also, the stoichiometric measurement of lipid to methanol is considered difficult, and much lipid is involved (about $1 \mathrm{~g}$ ). Further, the commercially obtained petroleum ether often contains materials which interfere with GLC peaks of methyl butyrate and methyl hexanoate, so the petroleum ether to be used must be refined by distillation.

The present study describes an analytical method to determine the fatty acid composition of food containing short chain fatty acids, us= ing a small amount of lipid (about $100 \mathrm{mg}$ ). Thus, stable fatty acid methyl esters were obtained from lipid by addition of diazomethane ethyl ether solution and $\mathrm{Na}$-methylate methanol solution, and extracted in $n$-hexane after addi $=$ tion of $3 \mathrm{~N} \mathrm{HCl}$ solution. The residual metha= nol in $n$-hexane solution was removed by washing with water. Standard solutions of short chain fatty acid methyl esters (of differ= ent concentration) were also treated as sample solutions, for the correction of their recovery by treatment. The short chain $(4 \sim 13$ and 16 : 0) fatty acid methyl esters, and the long chain
(14 24) fatty acid methyl esters of the sample were separately measured by GLC in different conditions. The complate fatty acid $(4 \sim 24)$ composition of the sample was obtained by combining these data of fatty acid methyl esters contents by mediation of methyl palmitate amount, since palmitic acid is the major fatty acids in many food lipids. As an example, the fatty acid composition of butter, margarine (containing milk fat) and coconut oil was de= termined.

\section{Methods}

\subsection{Materials}

Butter fat and margarine (containing 28\% milk fat in lipid) fat were obtained by extrace tion into ethyl ether from commercially availe able butter or margarine, and reagent coconut oil was used.

\section{$2 \cdot 2$ Reagents}

About $200 \mathrm{mg}$ of each pure $(99 \%+)$ short chain fatty acid methyl ester $(4: 0,6: 0,8: 0$, $10: 0,12: 0)$ and $400 \mathrm{mg}$ methyl palmitate $(99 \%+)$ were dissolved in $50 \mathrm{ml} n$-hexane to make fatty acid methyl ester undiluted standard solution. Methyl tridecanoate $(99 \%+) n$-hexane solution $(2.5 \mathrm{mg} / \mathrm{ml})$ was used as an internal standard for GLC analysis. As methylation reagents, diazomethane ethyl ether solution (from $\mathrm{N}$-methyl-N-nitroso urea) and $\mathrm{Na}$ methylate methanol solution (from small pieces of sodium metal and methanol) were made.

\subsection{Gas Liquid Chromatography (GLC)}

GLC was performed by Shimazu $9 \mathrm{~A}$ type gas liquid chromatograph equipped with FID detector and C-R $2 \mathrm{~A}$ integrator. Glass columns (i.d. $3 \mathrm{~mm} \times 2 \mathrm{~m}$ ) packed with the following materials were used: $5 \%$ PEGA coated on $80 /$ 100 mesh Chromosorb W; 20\% DEGS coated on 60/80 mesh Celite 545; Diasolid ZF 80/100 mesh; 5\% Advance DS coated on 80/100 mesh Chromosorb W; 10\% FFAP coated on 100/120 mesh Gaschrom Q; and 15\% OV-275 coated on $80 / 100$ mesh Chromosorb P.

\subsection{Experimental Methods}

$2 \cdot 4 \cdot 1$ Measurement of Base Line Drift on GLC

In the same GLC conditions except for the packing materials in the column, the base line of temperature programmed GLC by single 
column method was drawn (GLC conditions: column temperature $80 \sim 220^{\circ} \mathrm{C}$, program rate $10^{\circ} \mathrm{C} / \mathrm{min}$, injection temperature $230^{\circ} \mathrm{C}, \mathrm{N}_{2}$ flow rate $50 \mathrm{ml} / \mathrm{min}$, range $10^{2} \mathrm{M} \Omega$, recorder attenua= tion $32 \mathrm{mV}$ ). The base line drift was measur= ed by the difference $(\mathrm{cm})$ of base line level at column temperature $80^{\circ} \mathrm{C}$ and $220^{\circ} \mathrm{C}$.

\section{$2 \cdot 4 \cdot 2$ Measurement of Methanol}

Residual methanol in solution was measured by GLC on $20 \%$ DEGS column (GLC condi= tions: column temperature $65^{\circ} \mathrm{C}$, injection tem $=$ perature $150^{\circ} \mathrm{C}, \mathrm{N}_{2}$ flow rate $50 \mathrm{ml} / \mathrm{min}$ ).

$2 \cdot 4 \cdot 3$ Methylation of Lipid and Measure $=$ ment of Fatty Acid Methyl Esters

Lipids $(50 \sim 100 \mathrm{mg}$ ) were methylated by the method presented in Chart-1. A set of fatty acid methyl esters standard solutions (each short chain fatty acid methyl ester $0.2 \sim 20 \mathrm{mg} /$ $5 \mathrm{ml}$ ) was made from undiluted standard solu= tion, and treated as indicated in Chart 1 . The short chain (4 13 and 16:0) fatty acid methyl esters of samples and standard solutions were analysed by temperature programmed GLC on 15\% OV-275 column (GLC conditions: column temperature $80 \sim 220^{\circ} \mathrm{C}$, program rate $10^{\circ} \mathrm{C} / \mathrm{min}$, injection temperature $250^{\circ} \mathrm{C}, \mathrm{N}_{2}$ flow rate 50 $\mathrm{ml} / \mathrm{min}$ ), and their concentration of sample was measured by the $\log$--log calibration plots

Chart-1 Operation procedure.

\begin{tabular}{|c|c|c|}
\hline Lipid $(50 \sim 100 \mathrm{mg})$ & lipid $(50 \sim 100 \mathrm{mg})$ & $\begin{array}{l}\text { Fatty acid } \\
\text { methyl ester } \\
\text { standard } \\
\text { solution }(5 \mathrm{ml}) \\
\downarrow\end{array}$ \\
\hline \multicolumn{3}{|c|}{$\begin{array}{l}\text { + Diazomethane ethyl ether solution }(1 \mathrm{ml}) \\
+0.5 \mathrm{~N} \mathrm{Na} \text {-methylate methanol solution }(2 \mathrm{ml})\end{array}$} \\
\hline$\downarrow$ & $\downarrow$ & $\downarrow$ \\
\hline$+n$-Hexane $(1 \mathrm{ml})$ & \multicolumn{2}{|c|}{+ Internal standard solution $(1 \mathrm{ml})$} \\
\hline$\downarrow$ & $\downarrow$ & $\downarrow$ \\
\hline \multicolumn{3}{|c|}{$\begin{array}{l}\text { Shake vigorously and leave stand for } 30 \mathrm{~min} \\
+3 \mathrm{~N} \mathrm{HCl}(2 \mathrm{ml})\end{array}$} \\
\hline$\downarrow$ & $\downarrow$ & \\
\hline \multicolumn{3}{|l|}{$+n$-Hexane $(5 \mathrm{ml})$} \\
\hline$\downarrow$ & $\downarrow$ & $\downarrow$ \\
\hline \multicolumn{3}{|c|}{$\begin{array}{l}\text { Shake vigorously and leave stand for phase separation } \\
\downarrow \\
\text { Pour } n \text {-hexane phase ( } 4 \mathrm{ml} \text { ) into test tube } \\
\downarrow \\
\text { H.Distilled water ( } 2 \mathrm{ml} \text { ) into test tube } \\
\downarrow \\
\text { Shake vigorously and leave stand for phase separation } \\
\downarrow \\
\text { Pour } n \text {-hexane phase through filter paper (Toyo No. } 5 \mathrm{~A} \text { ) } \\
\text { into test tube to remove residual water in } n \text {-hexane phase }\end{array}$} \\
\hline
\end{tabular}

with treated standard solutions. The long chain (14 24) fatty acid methyl esters were analyse ed by isothermal GLC on 20\% DEGS column (GLC conditions: column temperature $190^{\circ} \mathrm{C}$, injection temperature $230^{\circ} \mathrm{C}, \mathrm{N}_{2}$ flow rate 50 $\mathrm{ml} / \mathrm{min}$ ): The quantitation was made by the peak area percentage method. The ratios of each fatty acid methyl ester amount to methyl palmitate were caculated for both short chain and long chain groups. The complate fatty acid (carbon number, 4 24) composition of the sample was obtained from these ratios.

\section{Results and Discussion}

\subsection{GLC Column for the Analysis of Short Chain Fatty Acid Methyl Esters}

The separation properties and the base line drift were examined by the temperature proo grammed GLC on several columns packed with different materials (5\% PEGA, 20\% DEGS, I)iasolid ZF, 5\% Advance $D C, 10 \% \mathrm{FFAP}$ and $15 \%$ OV 275 ; usually used for the analysis of fatty acid methyl esters). According to the results, the $15 \%$ OV 275 column was used in present study for the analysis of the short chain fatty acid methyl esters, because the base line drift was the smallest among them and its GLC separation property was desirable for their analysis.

\subsection{Residual Methanol in Sample Solution}

The treatment as shown in Chart-1 was performed except for the addition of lipid or standard, and the residual methanol in $n$-hexane phase was measured before or after washing. The residual methanol in petroleum ether solution of Christopherson's method $^{3}$ (no addition of lipid) was also measured. These data are shown in Table1. From the results of present method, a small amount of methanol was extracted into $n$-hexane phase and the residual me= thanol in $n$-hexane phase could be removed by washing, so that the GLC analysis of methyl butyrate was not hindered by me= thanol. In actual sample solution of Chri= stopherson's method ${ }^{33}$, by which the stoi= chiometric amount of lipid to methanol is added, the residual methanol will be less 
Table-1 Residual methanol in sample solution.

\begin{tabular}{l|l|c}
\hline \multicolumn{2}{c|}{ Method } & Methanol (\%) \\
\hline \multirow{2}{*}{ Present method* } & before wash & 0.63 \\
\cline { 2 - 3 } & after wash & 0.01 \\
\hline Christopherson's method ${ }^{3) *}$ & 2.50 \\
\hline
\end{tabular}

* : except addition of lipid

than shown by the data in Table-1. However, the residual methanol may virtually make the GLC analysis of methyl butyrate impossible, when the lipid amount is less than the equi= valent amount of methanol.

\section{$3 \cdot 3$ Recovery and Calibration Plots}

The short chain fatty acid methyl esters were somewhat soluble in water, so their recovery by extraction into $n$-hexane was examined at various concentration of fatty acid methyl ester standard solution which was treated as shown in Chart-1. The recovery of the fatty acid methyl esters is shown in Table-2, and the $\log \log$ calibration plots in Fig. 1 . The recoe very of methyl butyrate $(4: 0)$ and methyl hexanoate $(6: 0)$ is somewhat low, depending on the concentration. However, their $\log -\log$ calibration plots show a linear relationship over a wide concentration range of each fatty acid methyl ester, in spite of the lower sensitivity of their GLC peak area than that of methyl palmitate. Then these plots were used for

Table-2 Recovery of fatty acid methyl ester after treatment as Chart -1 .

\begin{tabular}{c|r|r|r}
\hline \multirow{2}{*}{ FAM $^{*}$} & \multicolumn{3}{|c}{ Recovery (\%) } \\
\cline { 2 - 4 } & \multicolumn{2}{|c|}{$\begin{array}{c}\text { FAM amount (mg) } \\
\text { in } 5 \text { ml standard solution }\end{array}$} \\
\cline { 2 - 4 } & $0.51 \mathrm{f}$ & $3.2 \mathrm{f}$ & $20 \mathrm{f}$ \\
\hline $4: 0$ & 66 & 79 & 86 \\
$6: 0$ & 86 & 93 & 99 \\
$8: 0$ & 95 & 95 & 100 \\
$10: 0$ & 95 & 98 & 100 \\
$12: 0$ & 100 & 100 & 100 \\
$16: 0$ & 100 & 100 & 100 \\
\hline
\end{tabular}

* FAM : fatty acid methyl ester

** $\mathrm{f}$ : factor of each fatty acid methyl ester in sample solution; 0.788 (for $4: 0$ FAM), 0.749 (for $6: 0 \mathrm{FAM}$ ), 0.815 for $8: 0 \mathrm{FAM}$ ), 0.757 (for $10: 0 \mathrm{FAM}$ ), 0.920 (for $12: 0 \mathrm{FAM}$ ), 1.883 (for $16: 0$ FAM)

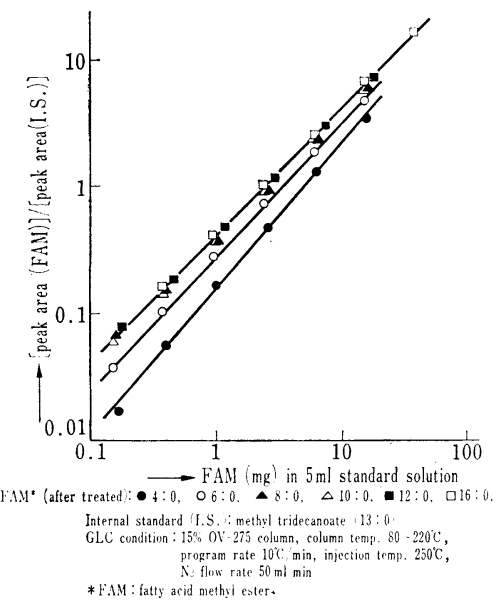

Fig. 1 Log-log calibration plots of fatty acid methyl ester.

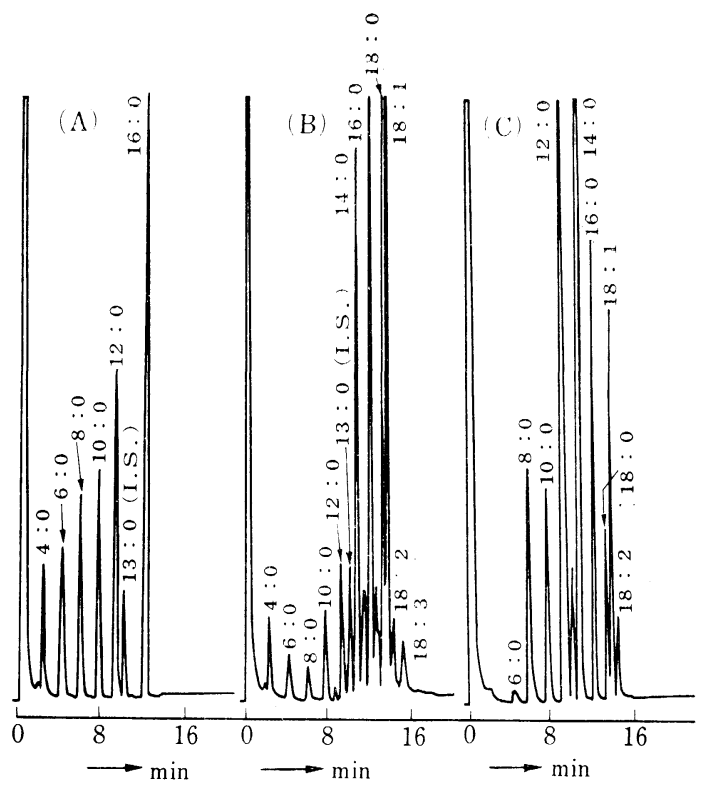

(A) Standard solution +internal standard I.S.

(B) Butter fat +I.S.

(C) Coconut oil +I.S

GLC condition: $15 \%$ OV-275 column, column temp. $80 \sim 220^{\circ} \mathrm{C}$, program rate $10^{\circ} \mathrm{C}$ min, injection temp. $250^{\circ} \mathrm{C}$ $\mathrm{N}_{2}$ flow rate $50 \mathrm{ml}$ min

Fig.-2 Gas liquid chromatogram.

their calibration, which also covered the correcs tion of their recovery. On the other hand, the $\log -\log$ calibration plots of methyl octanoate $(8: 0)$, methyl decanoate $(10: 0)$, methyl laus rate $(12: 0)$ and methyl palmitate $(16: 0)$ fitted 
Table-3 Fatty acid composition (\% as methyl ester)

\begin{tabular}{|c|c|c|c|}
\hline FAM $^{*}$ & Butter & Margarine** & Coconut oil \\
\hline $4: 0$ & 4.8 & 1.4 & - \\
\hline $6: 0$ & 2.6 & 0.6 & 0.8 \\
\hline $8: 0$ & 1.4 & 0.4 & 8.8 \\
\hline $10: 0$ & 3.1 & 0.8 & 6.5 \\
\hline $12: 0$ & 3.4 & 1.1 & 50.5 \\
\hline $14: 0$ & 9.8 & 3.1 & 15.2 \\
\hline $14: 1$ & 2.1 & 0.5 & - \\
\hline $16: 0$ & 22.8 & 17.4 & 7.7 \\
\hline $16: 1$ & 2.8 & 1.0 & - \\
\hline $18: 0$ & 11.6 & 8.2 & 2.3 \\
\hline $18: 1$ & 25.5 & 35.0 & 6.2 \\
\hline $18: 2$ & 2.5 & 27.6 & 1.7 \\
\hline $18: 3$ & 2.0 & 0.8 & 0.1 \\
\hline $20: 1$ & $0 . .3$ & 0.5 & - \\
\hline ()ther ${ }^{* * *}$ & 5.5 & 1.8 & 0.1 \\
\hline
\end{tabular}

almost the same regression equation (slope $\approx 1$ ). Thus, the sensitivity of the GLC peak of these fatty acid methyl esters was considered to be comparable.

\subsection{Fatty Acid Composition of Sample Lipids}

GLC chromatograms on OV-275 of short chain fatty acid methyl ester standard solution, butter fat and coconut oil are shown in Fig.2. The fatty acid composition of butter fat, margarine (containing milk fat) fat and coco= nut oil were measured by the present method, and the results are shown in Table-3. The recovery of lipid as the total fatty acid methyl ester content was $97.6 \%$ for butter fat, $98.5 \%$ for margarine fat, and $97.9 \%$ for coconut oil. These fatty acid methyl esters were stable for several days, so quick operations were not necessary the present method. Only a slight amount of methyl tridecanoate was detected in sample lipids examined, so methyl tridecanate is considered suitable as an internal standard for GLC analysis of fatty acid methyl ester.

We thank Dr. Masahiro Iwaida (Nestlé K.K.) for his valuable information.

(Received April 4, 1985)

\section{References}

1) H. Reichert, Z. Anal. Chem., 18, 69 (1879).

2) J. Kuhl and J. Grossfeld, Z. Untersuch. Lebensm., 51, 31 (1926).

3) S.W. Christopherson and R.L. Glass, J. Dairy Sci., 52, 1284 (1969).

4) Joint IDF/ISO/AOAC group of Experts E 10 (Chairman, Ir. J. Roos), IDF 59th Annual Sessions in Salzburg (1975) Commission E on detection of foreign fat in milk fat E-Doc 59.

5) M. Iwaida, Y. Ito, Y. Tonogai, and T. Wa $=$ tanabe, Jap. Food Hyg. Soc., 20, 328 (1979).

6) Ed. Pharm. Soc. Jap., "Standard Methods of Analysis for Hygienic Chemists with Com= mentary", p. 271, Kanehara Shuppan (Tokyo) 1980 (in Japanese).

\section{低級脂肪酸在含毛食监 0 ) 脂肪酸組成測定法:}

川井信子・中山行穂・传々未清沁 人服计泣噮摬科学研究所

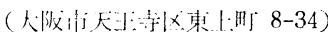

低級脂肪酸またはそのメチルエステルの高い揮発性及 び水溶性のため, このような脂肪酸を含む食品の脂肪酸 組成の分析は, 高級脂肪酸のみのものに比べて困難であ る。本報では, 少量（約 $100 \mathrm{mg}$ ）の脂質試料を用いて, 低級脂肪酸を含む食品の脂肪酸組成分析法が以下のよう に確立された。すなわち, 脂質をジアゾメタン及び $\mathrm{Na}-$ メチラートでメチル化し，生成した脂肪酸メチルエステ ルを $n$-へキサンで抽出する。低級脂肪酸メチルエステ ル（4 13 及び 16:0）を 15\% OV-275 カラムによる 昇温 GLC で, 高級脂肪酸メチルエステル (14 24)を 脂肪酸メチルエステルに適するカラム（例えば DEGS） による定温 GLC で測定し，これらのデータをパルミチ ン酸メチル量を仲介として，全脂肪酸組成 $(4 \sim 24)$ を測 定する(パルミチン酸は多くの食品の主な脂肪酸のひと つである)。バタ一脂質, マーガリン(乳脂肪含有) 脂質 及びやし油の脂肪酸組成が測定された。全脂肪酸メチル エステル量としての脂質の回収率は, バター脂質 $(97.6$ $\%$ )，マーガリン脂質 (98.5\%) 及びやし油 (97.9\%) で あーた。 